\title{
POLLEN AND MICROALGAE IN SEDIMENTS AT SOUTHERN MARGIN OF COLHUE HUAPI LAKE, CHUBUT, ARGENTINA. AN INSIGHT TO AMONG SHORE COMPARISON
}

\author{
ANÁLISIS DE POLEN Y MICROALGAS EN SEDIMENTOS DE LA MÁRGEN SUR DEL LAGO \\ COLHUE HUAPI, CHUBUT, ARGENTINA. UNA COMPARACIÓN ENTRE ORILLAS
}

\author{
Ana C. Fabiani ${ }^{1}$, Lidia S. Burry² \& Alicia H. Escalante ${ }^{3}$
}

\begin{abstract}
RESUMEN
Con el objetivo de conocer las comunidades vegetales del lago Colhue Huapi e inferir los cambios en el nivel del lago ocurridos durante el Holoceno Tardío, se analizó el contenido polínico y algal de un perfil de la margen sur, sitio La Campanita (45 38' S, 68 $37^{\circ}$ O). El segmento analizado posee dos dataciones ${ }^{14} \mathrm{C}$ (AMS), una de $1711 \pm 35{ }^{14} \mathrm{C}$ años AP a $95 \mathrm{~cm}$ de profundidad, correspondiente a la base del perfil, y otra de $979 \pm 42{ }^{14} \mathrm{C}$ años AP a $40 \mathrm{~cm}$. Se observó un predominio de taxa no arbóreos, de los cuales Chenopodiaceae fue el taxón arbustivo más importante y Cyperaceae el taxón herbáceo principal. El perfil mostró cambios a nivel local y pocas diferencias respecto del ingreso de polen regional y extra regional. Desde $1711 \pm 35{ }^{14} \mathrm{C}$ años AP hasta ca. 1212 años $\mathrm{AP}$, la baja representación de Cyperaceae - relacionada con una menor disponibilidad de sitios someros para colonizar - y los mayores porcentajes de las algas planctónicas estudiadas, sugieren un nivel alto del lago. Entre ca. 1212 y 414 años AP se observa un período de cambio en el nivel del lago, con reiteradas fluctuaciones. La tendencia se modificaría hacia $979 \pm 42{ }^{14} \mathrm{C}$ años AP con una disminución del nivel del agua indicado por una expansión de las Cyperaceae y una reducción de las algas. Desde ca. 414 años AP hasta ca. 195 años AP continuó el descenso del nivel del lago aunque con una tendencia más neta y menos fluctuante, indicado por los mayores porcentajes de Cyperaceae del perfil y más bajos para las algas. Para los últimos ca. 195 años AP se registró una recuperación del nivel del lago dada por una reducción de los porcentajes de Cyperaceae, y un leve aumento de las algas. Asimismo, el perfil La Campanita se comparó estadísticamente con un

\footnotetext{
${ }^{1}$ CONICET - Laboratorio de Limnología, Facultad de Ciencias Exactas y Naturales. Universidad Nacional de Mar del Plata. Funes 3250, 7600 - Mar del Plata, Argentina, afabiani@mdp.edu.ar

${ }^{2}$ UNMdP - Laboratorio de Palinología, Facultad de Ciencias Exactas y Naturales. Universidad Nacional de Mar del Plata. Funes 3250, 7600 - Mar del Plata, Argentina, lburry@mdp.edu.ar

${ }^{3}$ CONICET - Laboratorio de Limnología, Facultad de Ciencias Exactas y Naturales. Universidad Nacional de Mar del Plata. Funes 3250, 7600 - Mar del Plata, Argentina, aescalan@mdp.edu.ar
} 
perfl extraído de la margen noroeste del mismo lago. Ambas secuencias reflejaron tendencias similares de variaciones de nivel del lago para los intervalos anteriores a $979 \pm 42{ }^{14} \mathrm{C}$ años AP. orillas

Palabras clave: Polen, PNP, Holoceno, Lago Colhue Huapi, nivel del lago, comparación entre

\section{ABSTRACT}

A soil profile from the southern margin of Colhue Huapi Lake, at La Campanita site (453' S, $\left.68^{\circ} 37^{\prime} \mathrm{W}\right)$, was analysed for pollen and algae content to know the past vegetation communities and to infer changes in lake water level occurred during the Late Holocene. Samples were dated by AMS ${ }^{14} \mathrm{C}$ methods. Radiocarbon ages were of $1711 \pm 35{ }^{14} \mathrm{C}$ yr BP at the base, $95 \mathrm{~cm}$ depth, and another of 979 $\pm 42{ }^{14} \mathrm{C}$ yr BP at $40 \mathrm{~cm}$ depth. The record was dominated by no arboreal taxa, Chenopodiaceae being the principal shrub taxon and Cyperaceae the herbaceous one. Changes in the pollen record occurred mainly at a local scale and few differences were observed in the input of regional and extra regional pollen. From $1711 \pm 35{ }^{14} \mathrm{C}$ yr BP until ca. 1212 yr BP, a high lake water level was indicated by the low representation of Cyperaceae associated with few shallow areas available to be colonized and high percentages of Pediastrum and Botryococcus algae. Between ca. 1212 and $414 \mathrm{yr}$ BP a period of changes with several fluctuations in water depth developed. This trend would modify at $979 \pm 42{ }^{14} \mathrm{C}$ yr BP with a decrease in the waters reflected by the expansion of Cyperaceae and algal reduction. From ca. 414 yr BP until 195 yr BP lake water level continued falling with a less fluctuating and net trend as indicated by the highest percentage of Cyperaceae in the sequence and a low algal representation. The subsequent reduction in Cyperaceae percentage and the moderate increase in the algae would indicate a recovery of the lake water level for the last ca. $195 \mathrm{yr}$ BP. Additionally La Campanita sequence was statistically compared with a sequence obtained from the north-western margin of the lake. Both sites registered a similar trend before $979 \pm 42{ }^{14} \mathrm{C}$ yr BP.

Key words: Pollen, NPP, Holocene, Colhue Huapi Lake, lake water level, shore comparison.

\section{INTRODUCTION}

Lakes represent excellent continental climate archives since their deposits usually span over long periods of time and yield moderately high-resolution paleoenvironmental records (Fritz, 2005). Such sites offer simple continuous sedimentation, dominated by deposits of dead planktonic material that incorporate other particles, such as pollen and spores that are blown or washed into the lake (Bennett \& Willis, 2003).

Pollen analysis is an important method for the reconstruction of past vegetation by means of the pollen grains it produced (Faegri \& Iversen, 1989). Such reconstructions tend to incorporate other microfossils (Danielsen, 2010) of different origins that are often preserved in pollen preparations. These extra fossils, known as NPP (non-pollen palynomorphs) include remains of algae, cyanobacteria, spores of fungi and invertebrates, and increase paleoenvironmental information obtained from the samples (van Geel, 2003).

Patagonia is an important source of terrestrial paleoclimate data from the higher southern midlatitudes as it is the southernmost continental landmass in the southern hemisphere, except for Antarctica (Fey et al. 2009). However, well dated high resolution climate archives in southern South America and especially in Patagonia steppe are still scarce (Haberzettl et al. 2005; Wille et al. 2007; Kiliam \& Lamy, 2012).

Some paleoenvironmental researchs developed on lentic environments of Patagonia, at Santa Cruz province, include Cardiel Lake (Stine \& Stine, 1990; Markgraf et al. 2003), Laguna Potrok Aike (Haberzettl et al. 2005; Wille et al. 2007), Laguna Azul (Mayr et al. 2005) and Laguna Las Vizcachas (Fey et al. 2009) and incorporate diverse indicators such as pollen, microalgae, 
ostracods and stable isotopes.

In this way and taking into account that lake water level oscillation in closed basins is a good indicator of climatic variations (Stockton 1990, Mason et al. 1994), different approaches are taking place, in Colhue Huapi Lake, at Chubut province, to know past environments of central Patagonia. Previous researches include identification of prehistoric settlement sites in Colhue Huapi margins belonging to late huntergatherers (Arrigoni, 2001) ${ }^{1}$ and two palynological studies, one at Alero del Cañadón de las Manos Pintadas (Burry \& D'Antoni, 2001) located 50km West of the lake and the other on the north-western margin (Trivi \& Burry, 2007).

The aims of this study were a) to infer, through different palynomorphs (pollen and Pediastrum and Botryococcus algae), changes in vegetation and in Colhue Huapi Lake morphology during the Late Holocene, and b) to analyze the dynamics of the lake through the comparison of profiles from different shores.

\section{Study Area}

Colhue Huapi Lake is located at the southern area of Chubut province (45 $30^{\circ} \mathrm{S}, 68^{\circ} 45^{\prime} \mathrm{W}$ and $258 \mathrm{~m}$ asl) in the geomorphological region called Extra-Andean Patagonia (Fig. 1). Together with Musters Lake, they represent the greatest natural lentic environments along this region (Paruelo et al. 1998). Senguer River is the only influent of the system and its headwaters are located in the Andes mountain, in Fontana and La Plata Lakes (Fig. 1) (Calcagno et al. 1995; Montagna, 2007²). The main course of Senguer River divides before entering Musters Lake and contributes to Colhue Huapi Lake through an arm called Falso Senguer (Montagna 2007)2. From the south-eastern margin of Colhue Huapi Lake emerges the only effluent, Chico River, a temporary watercourse that flows into the Chubut River (Coronato \& del Valle, 1988).

1 Arrigoni, G. I. 2001. Relevamiento arqueológico en el área de perilago del Colhue Huapi. Evaluación de impacto arqueológico. Informe de impacto para GM\&A (MS), 18 pp.

2 Montagna, J. S. 2007. Geología del área del Cerro Negro en las nacientes del Río Chico, Provincia del Chubut. Tesis de licenciatura. Universidad de Buenos Aires, $151 \mathrm{pp}$.

3 Quirós, R. 1988. Mapas batimétricos y parámetros morfométricos de lagos patagónicos del Neuquén, de Río
Colhue Huapi is a shallow water body with a mean depth of $2 \mathrm{~m}$ and a surface area of $810 \mathrm{~km}^{2}$ (Quirós, 1988) ${ }^{3}$. It is a high irregular basin with a shoreline development (D) of 2.181 according to Dangavs equation (1995). A value of 1 for shoreline development is expected in lakes with circular morphometry and a larger value indicates that the shoreline is highly dissected (Dodds \& Whiles, 2010).

Colhue Huapi occupies a large shallow depression of structural and eolic origins. The deepest zones are located northward and near the Península Grande whereas the shallowest areas are in the southern area, in the vicinity of the outflow stream (Fig. 1) (Rivas, 1978) ${ }^{4}$. Oral records and satellite studies evidence the lake has undergone marked fluctuations in its morphology and water level in the last years (Coronato, 2003). Due to the shallowness of this waterbody, changes on the hydrologic budget originate big fluctuations in the basin area (Coronato, 2003; Tejedo, 20035).

The Lake is situated in an arid zone of Argentina with a mean annual precipitation of $150 \mathrm{~mm}$ and temperature of $10.9^{\circ} \mathrm{C}$ (Quirós et al. 1983). Winds from the West feature Patagonian climate and are characterized not only by their persistence during the year but also by their intensity and low humidity content (Paruelo et al. 1998). West to East decrease in precipitations in southern Chubut leads to a vegetation gradient from forest to different grass and shrub steppes (León et al. 1998).

Colhue Huapi belongs to the Chubutense subdistrict of the Patagonian phytogeographic province (Soriano, 1956). This subdistrict is characterized by a shrub steppe composed of desert and semi desert vegetation. Plants are adapted to drought and wind, and shrub species usually have spines and their leaves are reduced.

In plains above $400 \mathrm{~m}$ asl vegetation is dominated by shrubs such as Chuquiraga avellanedae Lorentz 1881, Nassauvia glomerulosa

Negro y del Chubut (Argentina). Informe técnico $N^{\circ} 5$. Informes Técnicos del Departamento de Aguas Continentales. Instituto Nacional de Investigación y Desarrollo Pesquero, 48 pp.

4 Rivas, A. 1978. Batimetría del lago Colhue Huapi. CENPAT Centro Nacional Patagónico, Contribución $\mathrm{N}^{\circ} 18: 1-8$.

5 Tejedo, A. G., 2003. Degradación de suelos en los alrededores del Lago Colhué Huapí, Escalante, provincia de Chubut. Servicio Geológico Minero Argentino-SEGEMAR. 


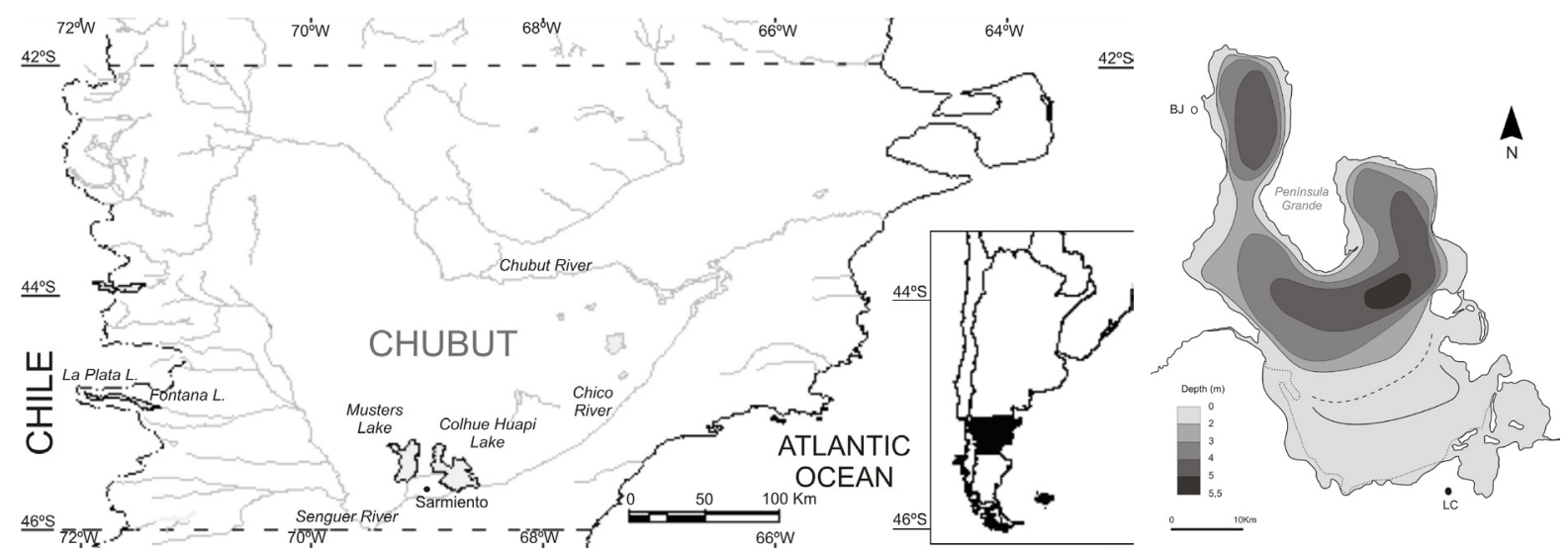

Fig. 1. Location of Colhue Huapi Lake, lake' bathymetry (modified from Rivas 1978)4. LC: La Campanita, BJ: Boliche de Jerez sites.

(Lindl.) D. Don 1832 and grass species as Stipa chrysophylla É.Desv. 1854, S. humilis Brot. 1804, S. speciosa Trin. \& Rupr. 1842 and Poa ligularis Nees ex Steud. 1854. In depressed areas halophyte species as Frankenia patagonica Speg. 1897, Lycium ameghinoi Speg. 1897, Prosopis denudans Benth. 1841 and the Chenopodiaceae Atriplex lampa (Moq.) D. Dietr. 1852 and Atriplex sagittifolia Speg. 1897 thrive. South of Colhue Huapi and Musters Lakes, halophyte vegetation alternates with Chuquiraga avellanedae and Nassauvia glomerulosa communities (Soriano, 1956; Paruelo et al. 1992). Senguer River originates a wide depositional plane entering the lakes covered by mallines. Moreover, periodically flooded places are usually covered by lawn of Juncus lesueurii Bol. 1863 and Poaceae such as Distichlis scoparia (Kunth) 1897 and D. spicata (L.) Greene 1887, which grow in brackish soils (Soriano, 1956; Correa, 1978).

\section{MATERIALS AND METHODS}

Twenty sediment samples were collected every $5 \mathrm{~cm}$ in a profile at the southern margin of Colhue Huapi Lake, in La Campanita site (45⒊'S $68^{\circ} 37^{\prime} W$ ) (Fig. 1). Two samples (14 and 18) were later divided in the laboratory in the subsamples inferior (i) and superior (s).

The extraction of pollen from sediments was performed according to Faegri \& Iversen standard procedures (1989). Three tablets of Lycopodium clavatum L. (1753) spores were added to each sample for a reassurance that no part of the sample has been lost during the extraction process. Subsequently, samples were sieved through a $260 \mu \mathrm{m}$ mesh. The material was deflocculated and humic acids were neutralized with potassium hydroxide. Chloride acid was added to remove carbonates. Organic and inorganic compounds were separated by differential flotation in a $\mathrm{ZnCl}$ solution $(\delta=1.9 \mathrm{~g} / \mathrm{l})$. Silicates were then removed with hydrogen fluoride (HF) and cellulose by acetolysis. Finally, residues were included in glycerine and transferred to $5 \mathrm{ml}$ vials.

Pollen was counted on microscope with $400 \mathrm{x}$ to $1000 \mathrm{x}$ magnification. Identifications were based on published atlases (Heusser, 1971; Markgraf \& D'Antoni, 1978; Moore et al. 1991) and on comparisons with a reference collection from the Palynology Laboratory (Universidad Nacional de Mar del Plata). Determination was done to class, family or genus level according to the resolution degree achieved at microscope. Samples were counted to a pollen sum of 300 grains excluding Cyperaceae and Monocotyledoneae (except Poaceae). Azolla and algae were also excluded from pollen sum. Percentages of Azolla and algae were based on total palynomorph sum including pollen, spores and algae. Statistical analysis was performed with taxa having more than $2 \%$ of total pollen sum in at least one sample. Constrained Cluster analysis was processed using the Orloci Distance (TGView 2.02, Grimm, 2004) and Ordination by correspondence analysis of Tilia pack, 1.12 version (Grimm, 1992). 
Table 1. AMS radiocarbon dates from core La Campanita of Colhue Huapi Lake.

\begin{tabular}{cccccc}
\hline Sample & $\begin{array}{c}\text { Depth } \\
(\mathrm{m})\end{array}$ & $\begin{array}{c}\text { Radiocarbon age } \\
\left({ }^{14} \mathrm{C} \text { years BP }\right)\end{array}$ & $\begin{array}{c}\text { Calibrated age } \\
(\text { cal yr BP })\end{array}$ & Dated material & Lab no. \\
\hline 1 & 0.95 & $1711 \pm 35$ & $1484-1630$ & Organic & AA69389 \\
12 & 0.40 & $979 \pm 42$ & $760-927$ & Organic & AA69390 \\
\hline
\end{tabular}

Additionally, a constrained Cluster analysis, using the Euclidean Distance, was performed with NPPs and pollen of the aquatic taxa (Azolla sp., Cyperaceae, Monocotyledoneae, Myriophyllum sp. and Triglochin sp.) to assess the dynamics of the aquatic communities.

Finally, La Campanita sequence (LC) was compared with the Boliche de Jerez (BJ) profile (Trivi \& Burry, 2007), obtained from the north-western margin of Colhue Huapi Lake, to analyze the dynamics of the water body. Taxa in common and having more than $2 \%$ of representation in at least one sample were used in the statistical analysis. Given that NPPs of BJ were not quantified but expressed in a qualitative scale (absent, poor and frequent), only pollen taxa were considered in the among sites comparison. $\mathrm{LC}$ and BJ samples were analyzed together by Cluster analysis without stratigraphic restriction and by Detrended Correspondence Analysis (DCA). Subsequently, LC and BJ scores of the first axis of common DCA were plotted against time to visualize the changes in the lake water level.

\section{Profile description}

La Campanita profile was divided in three lithological units as follows: a basal section having fine, homogeneous and wet sediment $(100-60 \mathrm{~cm}$ depth), a middle unit of rectangular and compact blocks with roots $(60-10 \mathrm{~cm}$ depth) and an upper section characterized by the presence of small blocks with a great density of roots and giant bulrush (Schoenoplectus californicus (C.A.Mey.) Soják 1972) macro-remains (10-0cm depth) (Fig. 2).

Radiocarbon ages of two samples were determined by AMS ${ }^{14} \mathrm{C}$ dating techniques at the Laboratory of Isotope Geochemistry of Arizona University (Table 1). Radiocarbon ages were then calibrated with the software Calib 5.1 Beta and corrected for the southern hemisphere, 2 sigma (Stuiver \& Reimer 1993). Chronology according to samples' depth was calculated with Tilia 1.7.15.

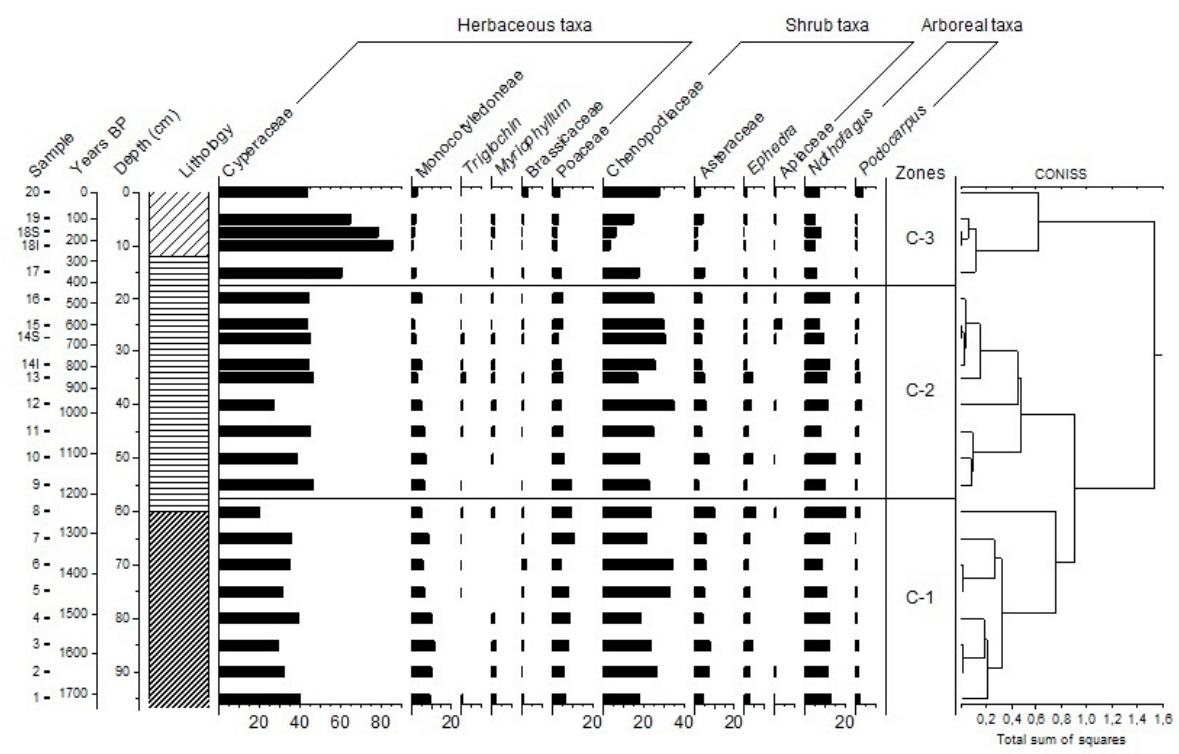

Fig. 2. Pollen diagram of taxa $>2 \%$. Samples, chronology, depth, lithology and pollen zones according to constrained cluster analysis are indicated. i: inferior, s: superior 
Sedimentation rate determined by depth and radiocarbon dates was of $0.075 \mathrm{~cm} \mathrm{yr}^{-1}$ before $979 \pm 42{ }^{14} \mathrm{C}$ yr BP and of $0.041 \mathrm{~cm} \mathrm{yr}^{-1}$ after that date.

\section{RESULTS}

In this study 21 pollen types, microspores of the free floating pteridophyte Azolla sp. and two non-pollen palynomorphs (NPPs) corresponding to the algal genera, Pediastrum and Botryococcus, were determined.

The pollen record was dominated by nonarboreal elements, including seven herbaceous and 11 shrub ones (Fig.2).

Cyperaceae, Monocotyledoneae and Poaceae were dominant among herbaceous taxa and Chenopodiaceae among shrub ones. As well, three extra regional taxa from the eastern fringe of subantartic forest Podocarpus, Nothofagus and Misodendron, a parasite of the latter, were found.

Constrained cluster analysis divided the profile in three zones (Fig. 2). From bottom to top the different units are characterized as follows:

C-1 $(95-57.5 \mathrm{~cm})$ : grouped samples 1 to 8 , from $1711 \pm 35{ }^{14} \mathrm{C}$ to ca. 1212 yr BP. This section was dominated by Cyperaceae (20-40\%) and Chenopodiaceae (18-34\%), and included the greatest percentages of Monocotyledoneae (5-11\%), Poaceae (5-11\%), Asteraceae (4-10\%), Ephedra sp. (2-6\%) and the arboreal taxon Nothofagus (8-20\%).

C-2 $(57.5-17.5 \mathrm{~cm})$ : samples 9 to 16 , from ca. 1212 to 414 yr BP. In this zone Cyperaceae and Chenopodiaceae still remained the dominant taxa. Chenopodiaceae ranged from 17 to $35 \%$, Monocotyledoneae (1-7\%), Poaceae (2.5-9\%) and Asteraceae $(<7 \%)$ percentages declined from the previous zone.

Ephedra sp. declined compared to the underlying zone and from samples $14 \mathrm{i}$ to 16 the percentages were slightly lower $(1-2 \%)$ and constants.

Among arboreal taxa, Nothofagus oscillated between 7 and 15\% whereas Podocarpus values were low and moderately constant at the top of the zone (samples 14i to 16).

The aquatic taxa Triglochin and
Myriophyllum reached high values towards the middle of this unit.

C-3 $(17.5-0 \mathrm{~cm}): 17$ to 20 samples included the latest ca. $414 \mathrm{yr}$ BP. Cyperaceae dominated this zone and reached the maximum percentages for the entire record, whereas Chenopodiaceae decreased and showed the lowest ones. Monocotyledoneae, Myriophyllum, Poaceae, Asteraceae and Ephedra decreased as well.

Arboreal taxa were poorly represented in this zone, except for Podocarpus at the surface sample.

The surface sample markedly differed from the others of the same zone. This sample was characterized by the lowest percentages of Cyperaceae (44\%) and the highest values of Chenopodiaceae (28\%), Monocotyledoneae (3\%), Brassicaceae (3\%) and Podocarpus (4\%), while the aquatic genus Myriophyllum was not represented.

Ordination of pollen samples by means of correspondence analysis explained $63 \%$ of the variance with the first axis and $20 \%$ with the second axis (Fig. 3-a). Samples were mainly arranged according to the cluster analysis of Fig. 2 .

Samples belonging to zone $\mathrm{C}-1$ and sample 10 from C-2, were grouped near the right edge of axis 1 and the bottom of axis 2. Accordingly, the variables explaining this ordination were Ephedra, Asteraceae and Chenopodiaceae, among shrub taxa; Monocotyledoneae and Poaceae, among herbaceous taxa and Podocarpus sp. and Nothofagus sp., among arboreal taxa (Fig. 3-b).

The remaining samples of C-2 and sample 20 were located at the middle of the first axis and more scattered along the second axis. Chenopodiaceae, Brassicaceae, Nothofagus sp. and the aquatic genera Myriophyllum and Triglochin explained the ordination of these samples (Fig. 3-b).

Finally, samples of C-3 stayed in the left edge of the first axis and Cyperaceae was the main variable determining this group (Fig. 3-b).

\section{Analysis of non-pollen palynomorphs} and other aquatic taxa

The constrained cluster analysis of the communities of aquatic vegetation divided the record in two zones (Fig. 4):

Zone $1(95-33.5 \mathrm{~cm})$ : grouped 1 to 13 
samples from $1711 \pm 35{ }^{14} \mathrm{C}$ yr BP to ca. 822 yr BP. This unit was dominated by Pediastrum sp. $(40-70 \%)$ and in a lesser extent by Botryococcus sp. $(<8 \%)$.

Cyperaceae (20-47\%) was dominant among aquatic plants, Monocotyledoneae, Triglochin sp. and Myriophyllum sp. were present in a lower proportion.

Zone $2(33.5-0 \mathrm{~cm})$ : includes $14 \mathrm{i}$ to 20 samples, from ca. 822 yr BP to the present. This zone showed decreased contribution of algae with respect to total palynomorphs and increased
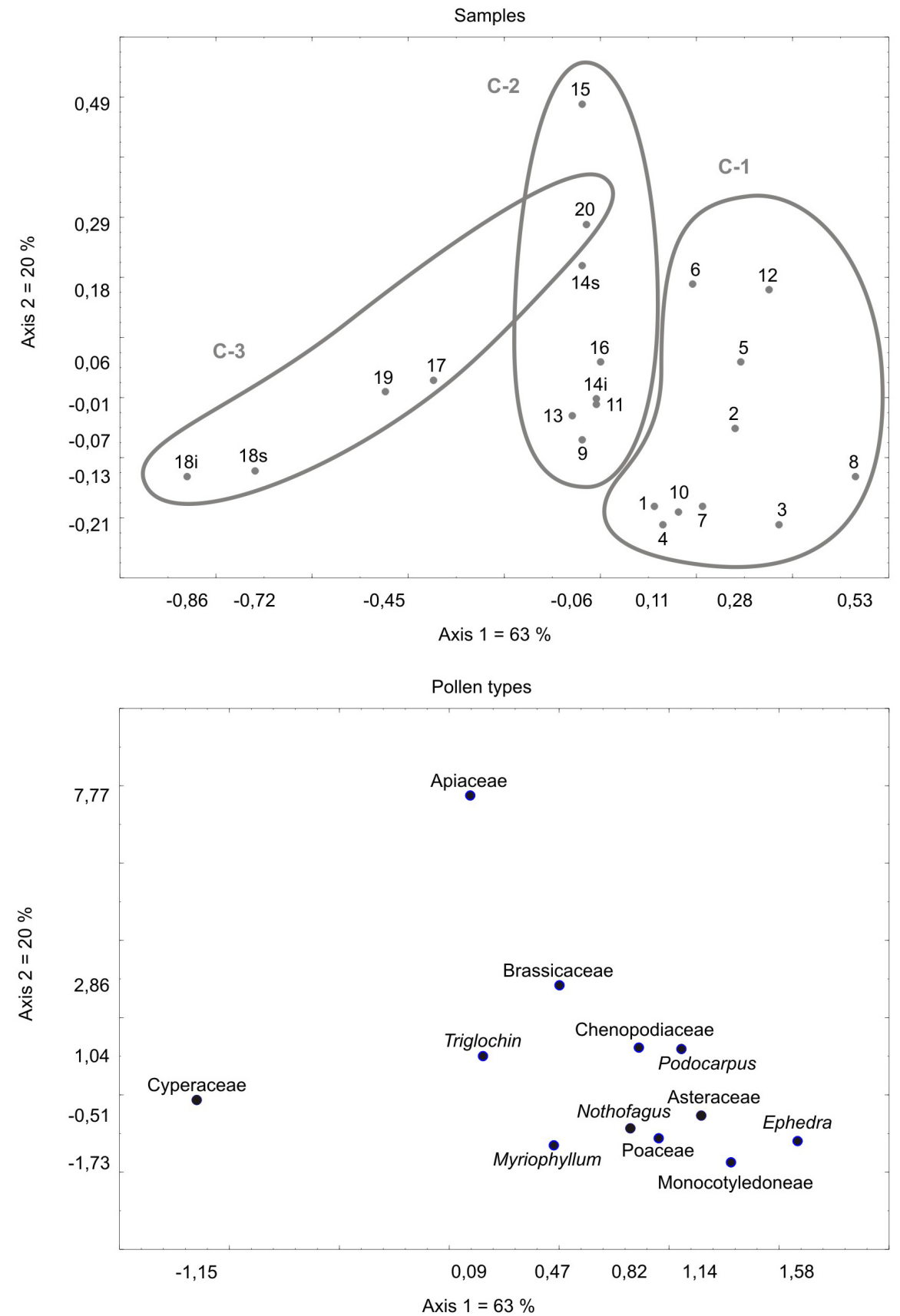

Fig. 3. First two axis of Correspondence analysis. a) Samples scores. b) Pollen variable scores. i: inferior, s: superior. 
representation of aquatic plants, mainly Cyperaceae (44-86\%) and Azolla sp. (<7\%). The other aquatic taxa were poorly represented.

\section{Comparison with Boliche de Jerez (BJ) profile}

La Campanita pollen spectrum (LC) was compared with Boliche de Jerez pollen assemblage (BJ) studied by Trivi \& Burry (2007) (Fig. 5). In both sequences non arboreal taxa predominated. $\mathrm{LC}$ and $\mathrm{BJ}$ shared seven pollen types though the contribution of some of them (herbaceous taxa Monocotyledoneae and Poaceae) was higher at BJ. On the other hand, Chenopodiaceae (a shrub taxon) was higher at LC. Those differences were also found in surface samples (LC20 and BJ13).

A common cluster analysis of LC and BJ delimited five groups (Fig. 5). Only one of these included samples of both sites. Both spectra were grouped separately and in the same way as in individual analyses.

The ordination of pollen samples along first axis of DCA of both profiles versus time was performed in order to visualize, through the response of both sites, the changes in lake water level experienced at both margins. LC and BJ samples arranged separately (Fig. 6). The irregularity of the curve suggests rapid environmental shifts with changes among wet and dry phases. Before ca. 1000 yr BP both sites shared a trend at similar timescales but they were to some extent outof-phase. From bottom to top the first increase along axis 1, was recorded earlier at LC3 than at BJ. Afterwards, both profiles showed an almost simultaneous decline at LC6 and BJ4 (Fig.6).

\section{DISCUSSION}

Pollen rain can be divided into different components according to the distance from its source. From further to nearer pollen is classified as extra-regional, regional, extra-local and local (Janssen, 1966). La Campanita pollen can be analysed through those elements. Arboreal taxa could not be attributed to the nearby vegetation of Colhue Huapi Lake; instead they are an example of

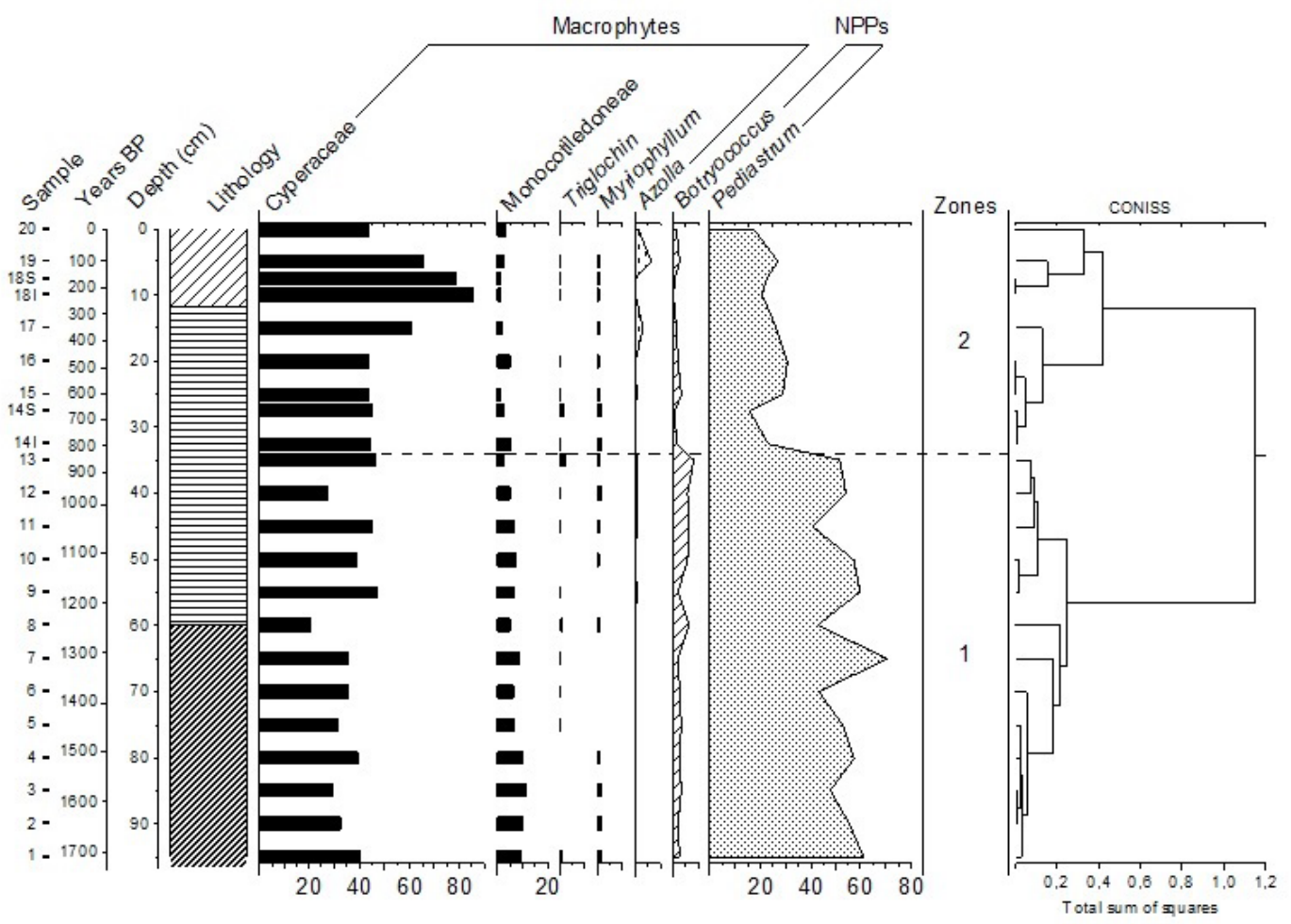

Fig.4. Pollen diagram of aquatic taxa and NPPs. Sample, chronology, depth, lithology and pollen zones according to constrained cluster analysis are indicated. i: inferior, s: superior. NPPs: Non-pollen Palynomorphs. 


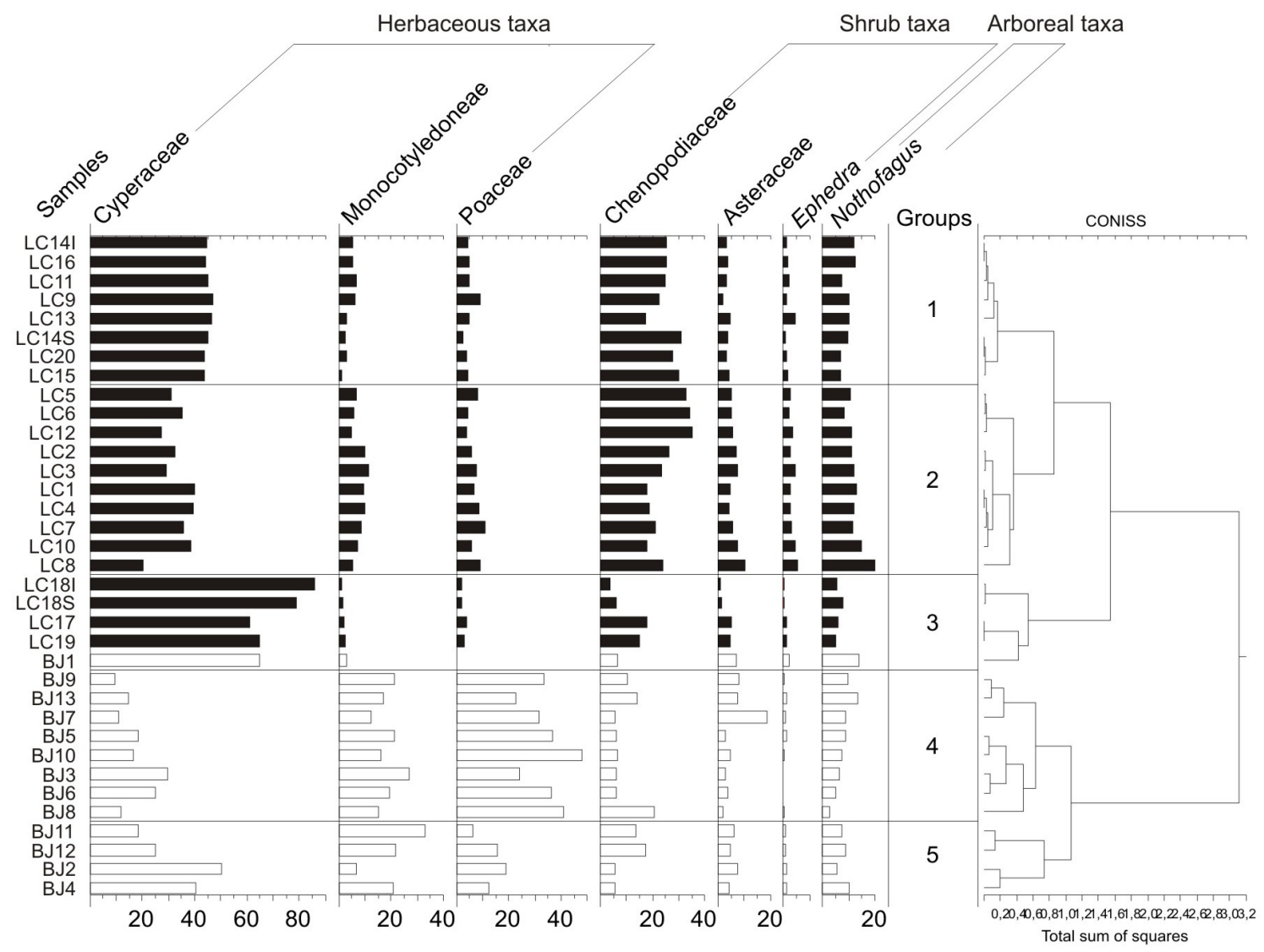

Fig.5. Groups defined by the unconstrained cluster analysis of La Campanita (LC, black bars) and Boliche de Jerez (BJ, white bars) samples. i: inferior, s: superior.

extra regional pollen coming from the subantartic forest on the west. The preponderance of Nothofagus species, in the forest, was also detected in the pollen spectrum as its pollen predominated among arboreal taxa throughout the record. Its presence might be due to air transport by constant winds from the west and by water transport through Senguer River input since La Plata and Fontana lakes basins are covered by Nothofagus trees (Calcagno et al. 1995, Modenutti et al. 1998). Today Podocarpus species occur mainly in occidental slopes of Los Andes, mostly in the Chilean side, and the distribution ranges southward 40 'S (Donoso \& Utreras, 2007; Donoso et al. 2007). Thus the observed contribution to the pollen assemblage might be due to the influence of constant winds from the west. In agreement with La Campanita, other records of extra Andean Patagonia also show input of Andean forest elements (Markgraf et al. 2003; Wille et al. 2007).

On the other hand, non arboreal taxa, that dominated the whole record, represent the local and regional elements. Poaceae pollen might belong to the halophyte species Distichlis scoparia and D. spicata that thrive on desiccated shore areas around these water bodies. Thus it can be considered a local component.

Chenopodiaceae are another halophyte taxa. At present in Colhue Huapi, Atriplex lampa and $A$. sagithifolium grow at Sarmiento basin and in the south of the lakes where the extensive evaporation of water originates large salt areas (Iglesias de Cuellos, 1982; Correa, 1984). As Chenopodiaceae representation decline rapidly with distance to the source (Markgraf et al. 2003), the abundant Chenopodiaceae pollen found at La Campanita was attributed to those species and is considered a local component too. 


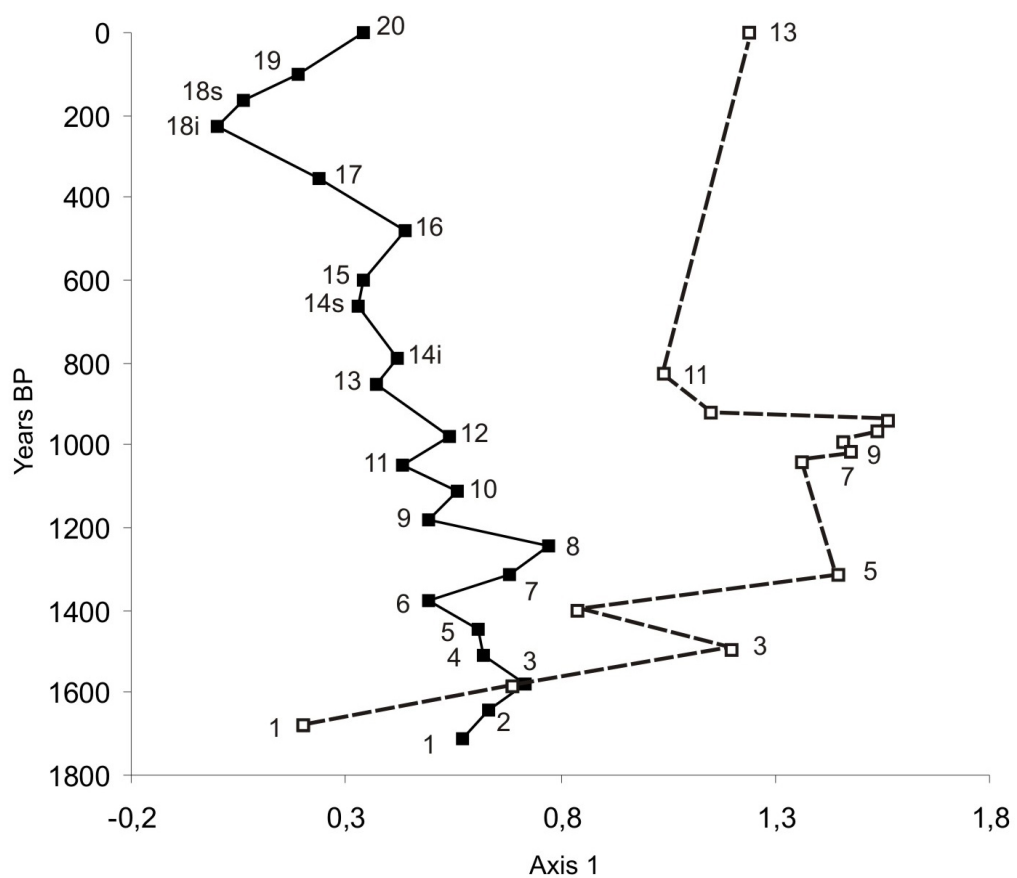

Fig.6. First axis of DCA of La Campanita (solid line and dark squares) and Boliche de Jerez (dashed line and open squares) samples vs. time. i: inferior, s: superior.

Cyperaceae, Triglochin and Myriophyllum are hidrophytes; thus they would represent autochthonous pollen of the lake.

The remaining non arboreal taxa might belong to regional pollen of the steppe. This regional pollen was the richest one compared to the other components even though the individual representation was low, with most taxa under $2 \%$. Shrubs represent the principal cover of the steppe (de la Vega, 2010).

In the Patagonian steppe there are three functional groups that responds in a similar manner to perturbations such as intense droughts. These are: coirones (short and compact perennial grasses), shrubs and herbs. Usually, herbs endure more intense drought conditions than shrubs (de la Vega, 2010; Golluscio et al. 2011).

Two local taxa, Cyperaceae and Chenopodiaceae, clearly dominated the pollen spectrum. One reason of this greater representation of local pollen respect to the regional one, might be the different pollen production and dispersal. For instance, the dominant species of the region, the Asteraceae Nassauvia glomerulosa and Chuquiraga avellanedae, are zoophilous plants and so have a small pollen production and liberation. Instead, Cyperaceae and Chenopodiaceae are wind pollinated plants and abundant pollen producers (de la Vega, 2010). Another reason might be the location of the sampling site. Other studies developed at ExtraAndean Patagonia's lakes (Markgraf et al. 2003; Trivi \& Burry, 2007) present a similar pattern. At low lying places, such as lacustrine environments of arid regions, the regional picture can be masked by pollen produced locally (Horowitz, 1992). Not only higher percentages of wind pollinated plants but also greater abundances of plants that contribute minimal amounts of pollen to the pollen rain. In this way regional elements might be recognizable not in percentages but in number of taxa.

In terms of water level, increased input of pollen of local halophytes might suggest an expansion of desiccated areas close to the shore during a period with low lake level (Mayr et al. 2005)

On the other hand, Cyperaceae usually indicates the presence of wet habitats in peat bogs (Mancini, 1998; 2009) or in lakes (Whitlock et al. 2006). Laine et al. (2010) associated the increase 
in Cyperaceae to a reduction of the water level of the pond. As La Campanita site is located at the shallowest zone of the lake, we also associated increased Cyperaceae input to a drier situation. Littoral helophytes can expand towards the middle of the wetland when low water level originates more extensive shallow water areas (Rossi \& Tur, 1976; Coops et al. 2003; Mayr et al. 2005).

The Pediastrum remains found in surface samples at La Campanita might not only be an example of the resistance of this algae cell wall (Weckström et al. 2010) but also it might be an evidence of a previously under water place. As instance, some years after Footprint Lake in Alaska was artificially drained, sediments were still rich in Pediastrum colonies (Livingstone et al. 1958). In agreement to this, oral evidence suggests that LC site had been under water in the 60's (Juan Vera personal communication).

At present Pediastrum colonies occur predominantly in the plankton in temperate eutrophic lakes, whereas in oligotrophic lakes Pediastrum taxa are often confined to the littoral zone associated to aquatic macrophytes (Weckström et al. 2010). Many algae, including Pediastrum, persist in littoral macrophytes when multiplication rates in free water reduce and cannot compensate the lost (Margalef, 1983). As littoral macrophytes stabilise bottom and enhance sediment accumulation (Dearing, 1997), a positive correlation between Cyperaceae and algae would be expected. However, this is not supported by La Campanita data.

Several paleoecological studies relate increase in Pediastrum with decreasing water depth (Markgraf et al. 2003; Whitlock et al. 2006), while others associate the decline of this algae with decreasing water level (Laine et al. 2010). Fey et al. (2009) found a positive correlation between abundance of littoral vegetation and epiphitic diatoms. In addition, the highest percentages of epiphitic taxa occurred at the expense of the planktonic ones. At La Campanita we found a negative correlation between littoral vegetation and Pediastrum and Botryococcus planktonic algal genera. Higher percentages of Cyperaceae occurred when algae values were low. At present a similar trend is found in the two alternative states of shallow lakes. In which the clear state is dominated by aquatic vegetation and has low algal biomass, and the turbid one is characterized by high algal biomass and poor aquatic vegetation (Scheffer et al. 1993). Furthermore an important factor for the switch between those alternative equilibria is the change in the water level (Scheffer et al. 1993).

The main change in Pediastrum sp. and Botryococcus sp. observed at LC from ca. $979 \pm$ $42{ }^{14} \mathrm{C}$ yr BP, was probably due to a bigger alteration in lake conditions than the ones observed in the algae before and after that time. This change, such as a low lake level, also triggered the expansion of Cyperaceae. Consequently if it is so, the Colhue Huapi Lake could have switched from a turbid to a clear state around $979 \pm 42$ yr BP (Fabiani et al. 2009).

The present reconstruction of Colhue Huapi, based on the cluster and ordination analyses, suggests that the lake went through several water level fluctuations during the timescale analysed. From $1711 \pm 35{ }^{14} \mathrm{C}$ yr BP to ca. 1212 yr BP low percentages of Cyperaceae related with few shallow habitats available for colonization and high values of the algae studied might suggest high lake water level.

Water levels higher than today are testified by archaeological remains found near La Campanita and dating ca. 1500 yr BP and ca. 1250 yr BP. Arrigoni $(2001)^{1}$ proposed that those places have been the bottom of the lake during the highest lake water level. In agreement with Arrigoni (2001) pollen samples for those dates indicate high water level.

Between ca. 1212 and 414 yr BP a period of changes with several water level fluctuations developed, as shown by the changes in Cyperaceae until ca. $979{ }^{14} \mathrm{C}$ yr BP. This trend would modify at ca. $979{ }^{14} \mathrm{C}$ yr BP with a higher constancy in Cyperaceae values. Cyperaceae could expand to newer shallow regions and the decrease in algae might reflect a reduction in water level. From ca. 414 yr BP to 195 yr BP lake level would have continued to decrease with a less fluctuating and net trend as indicated by the highest percentages of Cyperaceae of the sequence and low of the algae. The increase in Azolla percentages after ca. 414 yr BP would agree with a low lake water level since this free floating pteridophyte grows in environments with still waters and reduced flow 
(Carrapiço, 2001).

At present, the sampling site LC is dried up, but according to oral evidence around the second half of XX century the lake registered higher levels than today. The less fluctuating trend found in $\mathrm{La}$ Campanita from ca. 195 yr BP is not supported by historical nor oral records which indicate that repeated fluctuations of Colhue Huapi Lake have occurred since 1800 (Arrigoni, 2001루 ; Coronato, 2003, Juan Vera personal communication). Due perhaps to a low resolution of the profile, the short term variations in water level observed in the last years were not registered. As instance, a huge reduction of water level occurred in 2000 and five years later the lake had recovered (Tejedo, 20035; Casal et al. 2007). Part of those changes might be due to human impact. During dry seasons, the connection between Musters and Colhue Huapi Lakes is cut off, reducing the flow towards the later (Coronato, 2003; Tejedo, 200355; Secr. Recursos Hídricos Nación, 20076).

Other lakes of Patagonia showed a recession in the last century (Laguna Potrok Aike, Haberzettl et al. 2005). Lago Cardiel instead, after its latest low stand in 1990, has risen approximately $4 \mathrm{~m}$ (Markgraf et al. 2003).

The comparison of $\mathrm{LC}$ with the $\mathrm{BJ}$ sequences from the north-western margin of the lake showed differences in sedimentation rates. As instance, sediment yielded an age of $979 \pm 42{ }^{14} \mathrm{C}$ yr BP at $40 \mathrm{~cm}$ depth at La Campanita whereas at Boliche de Jerez an age of $920 \pm 35{ }^{14} \mathrm{C}$ yr BP was already observed at only $18 \mathrm{~cm}$ (Trivi \& Burry, 2007). This might be explained by a different sedimentation dynamics among margins (Dearing, 1997).

The sampling sites might influence the way changes in lake level are perceived. BJ profile was obtained from the paleo beach located at the west arm of the lake. The depressed areas west and east of Península Grande are due to soft synclines (Sciutto, 2003) ${ }^{7}$.

The LC assemblage is from the southern shore of the lake, where Senguer River enters Sarmiento plain (Bajo de Sarmiento) and originates

\footnotetext{
${ }^{5}$ Tejedo, A. G., 2003. Degradación de suelos en los alrededores del Lago Colhué Huapí, Escalante, provincia de Chubut. Servicio Geológico Minero Argentino-SEGEMAR.

${ }^{6}$ Secretaría de Recursos Hídricos de la Nación. 2007. Estudio de impacto ambiental, Presa "Los Monos" - Provincia de Chubut.
}

a floodplain of more of $200 \mathrm{~km}^{2}$ area (Sciutto, 2003) ${ }^{7}$.

Moreover the north-western area of the lake is deeper and presents steep margins whereas the southern zone is shallower and lake level changes are more intensively experienced (Rivas, 1978 Coronato, 2003).

Probably a bigger homogeneity in the records could be expected from sequences obtained from a more regular water body. Given that Colhue Huapi is a highly irregular watershed (with a $\mathrm{D}=2.181$ ) variations might not be perceived in a uniform manner.

Lake sedimentation processes are complex even in apparently simple basins and the vulnerability of the lakeshore to erosion is varied and would depend on slope profile, soil composition, sediment types and compactness (Dearing, 1997). One difficulty of using near-shore cores is that it is possible that part of the sediment archive may be lacking as a result of reworking of previously deposited sediment or wave action (Dearing, 1997; Laird \& Cumming, 2009). Thus the determination of an appropriate site, such as locations with sheltered margins, is a key component in lake-level reconstruction (Dearing, 1997). This might be done if accumulation of near shore sediments is adequate or by defining the dominant sedimentation mechanisms through the study of bathymetric maps as instance (Dearing, 1997; Laird \& Cumming, 2009).

When analysing $\mathrm{LC}$ and $\mathrm{BJ}$ records with others of extra Andean Patagonia, Cardiel Lake (Stine \& Stine, 1990; Markgraf et al. 2003), Laguna Potrok Aike (Haberzettl et al. 2005; Wille et al. 2007), Laguna Azul (Mayr et al. 2005) and Laguna Las Vizcachas (Fey et al. 2009), some inconsistencies appear. Hence some wet and dry periods seem to be out-of-phase and do not reveal a clear trend (Table 2).

Water-level fluctuations are the result of a change in the water budget and, therefore, depend on the amounts of precipitation and evaporation, catchment size and characteristics, and on the

\footnotetext{
7 Sciutto, J. C. 2003. Curso de Geología de campo: Comodoro Rivadavia - Sierra de San Bernardo. Universidad Nacional de la Patagonia "San Juan Bosco". http://www.fcn.unp.edu.ar/catedras/ sedimentologia/Guiadecampo.pdf
} 
Table 2. Climatic tendencies at regional scale for the timescale studied in La Campanita profile.

\begin{tabular}{|c|c|c|c|c|c|c|c|}
\hline Years BP & $\begin{array}{c}\text { Laguna } \\
\text { Azul }\end{array}$ & $\begin{array}{c}\text { Laguna } \\
\text { Potrok Aike }\end{array}$ & $\begin{array}{c}\text { Laguna Las } \\
\text { Vizcachas }\end{array}$ & Lago Cardiel & $\begin{array}{c}\text { Alero de } \\
\text { Las Manos } \\
\text { Pintadas }\end{array}$ & $\begin{array}{c}\text { Boliche de } \\
\text { Jerez }\end{array}$ & $\begin{array}{c}\text { La } \\
\text { Campanita }\end{array}$ \\
\hline & $\begin{array}{l}\left(52^{\circ} 05^{\prime} \mathrm{S},\right. \\
\left.69^{\circ} 35^{\prime} \mathrm{W}\right)\end{array}$ & $\begin{array}{l}\left(51^{\circ} 58^{\prime} \mathrm{S},\right. \\
\left.70^{\circ} 23^{\prime} \mathrm{W}\right)\end{array}$ & $\begin{array}{l}\left(50^{\circ} 42^{\prime} \mathrm{S},\right. \\
\left.71^{\circ} 59^{\prime} \mathrm{W}\right)\end{array}$ & $\begin{array}{l}\left(48^{\circ} 48^{\prime} \mathrm{S},\right. \\
\left.71^{\circ} 13^{\prime} \mathrm{W}\right)\end{array}$ & $\begin{array}{l}\left(45^{\circ} 28^{\prime} \mathrm{S}\right. \\
\left.69^{\circ} 42^{\prime} \mathrm{W}\right)\end{array}$ & $\begin{array}{l}\left(45^{\circ} 15^{`} \mathrm{~S}\right. \\
\left.68^{\circ} 53^{`} \mathrm{~W}\right)\end{array}$ & $\begin{array}{l}\left(45^{\circ} 38^{\prime} \mathrm{S},\right. \\
\left.68^{\circ} 37^{\prime} \mathrm{W}\right)\end{array}$ \\
\hline & $\begin{array}{c}\text { Mayr et al. } \\
2005\end{array}$ & $\begin{array}{l}\text { Haberzettl } \\
\text { et al. } 2005\end{array}$ & $\begin{array}{c}\text { Fey et al. } \\
2009\end{array}$ & $\begin{array}{c}\text { Stine \& } \\
\text { Stine, 1990; } \\
\text { Markgraf et } \\
\text { al. } 2003\end{array}$ & $\begin{array}{l}\text { Burry \& } \\
\text { D'Antoni, } \\
2001\end{array}$ & $\begin{array}{l}\text { Trivi \& } \\
\text { Burry, } \\
2007\end{array}$ & $\begin{array}{l}\text { Present } \\
\text { study }\end{array}$ \\
\hline- & & $\downarrow$ level & & $\begin{array}{c}\downarrow \text { lev. 1940- } \\
90 \mathrm{dC}\end{array}$ & \multirow{14}{*}{$\begin{array}{c}1300 \mathrm{BP}- \\
\text { present } \\
+ \text { dry }\end{array}$} & \multirow{10}{*}{$\begin{array}{c}920 \mathrm{BP} \text { - } \\
\text { present } \\
\uparrow \text { level }\end{array}$} & \multirow{3}{*}{$\begin{array}{c}195 \mathrm{BP}- \\
\text { present }\end{array}$} \\
\hline 50 & $\begin{array}{c}250-50 \\
\text { BP }\end{array}$ & & & & & & \\
\hline 150 & $\uparrow$ level & & & & & & \\
\hline 250 & & & $\begin{array}{c}300-200 \\
\mathrm{BP} \uparrow \mathrm{T}^{\circ}\end{array}$ & & & & \multirow[t]{2}{*}{$\begin{array}{c}414-195 \\
\text { BP }\end{array}$} \\
\hline 350 & $\begin{array}{c}600-300 \\
\text { BP }\end{array}$ & & $\begin{array}{c}500-300 \\
\text { BP }\end{array}$ & & & & \\
\hline 450 & Dry & & $\downarrow \mathrm{T}^{\circ}$ & & & & \multirow{6}{*}{$\begin{array}{c}979-414 \\
\text { BP }\end{array}$} \\
\hline 550 & & $\begin{array}{c}710-540 \\
\text { BP }\end{array}$ & & & & & \\
\hline 650 & & $\downarrow$ level & $\begin{array}{c}850-650 \\
\text { BP }\end{array}$ & & & & \\
\hline 750 & & & $\uparrow$ precipit & & & & \\
\hline 850 & & & & $\begin{array}{c}\text { lake } \\
\text { transgression }\end{array}$ & & & \\
\hline 950 & & & & & & $\begin{array}{c}1360-920 \\
\text { BP }\end{array}$ & \\
\hline 1050 & & & & & & $\downarrow \downarrow$ level & \multirow[t]{2}{*}{$\begin{array}{c}1212-979 \\
\text { BP }\end{array}$} \\
\hline 1150 & & & & & & $\begin{array}{c}\text { Lowest } \\
\text { level }\end{array}$ & \\
\hline 1250 & & & & & & & \multirow{6}{*}{$\begin{array}{c}1711 \text { - } \\
1212 \mathrm{BP} \\
\uparrow \text { level }\end{array}$} \\
\hline 1350 & & & & & \multirow{5}{*}{$\begin{array}{c}1700- \\
1300 \mathrm{BP} \\
+ \text { wet }\end{array}$} & $\begin{array}{c}1586 \text { - } \\
1360 \mathrm{BP}\end{array}$ & \\
\hline 1450 & & & & $\begin{array}{c}\uparrow \text { level } 1450 \\
\text { BP }\end{array}$ & & $\downarrow$ level & \\
\hline 1550 & & & & & & $\begin{array}{l}\text { Before } \\
1586 \text { BP }\end{array}$ & \\
\hline 1650 & & & & & & †level & \\
\hline 1750 & & & & & & $\begin{array}{l}\text { Highest } \\
\text { level }\end{array}$ & \\
\hline
\end{tabular}

discharge conditions (inflow versus outflow) of the basin (Hofmann et al. 2008).

They are connected to climatic changes, changes in the large atmospheric pressure systems, or, to seasonal variations and to anthropogenic use of water resources.
In general fluctuations relate to climate in such a way that colder and / or wetter phases are linked with high lake water levels while warmer and/or drier phases with low levels (Shennan, 2005). However basins and catchments having differences in area and volume can differ in the 
magnitude and moment of change in response to the same climatic forces (Mason et al. 1994). This might explain, in part, the dissimilarities at the beginning of dry and wet periods observed at the paleoreconstructions.

On the other hand, a higher correspondence was found when contrasting with Alero del Cañadón de las Manos Pintadas record (Burry \& D'Antoni, 2001), which might probably be due to its proximity. Before ca. $1300{ }^{14} \mathrm{C}$ yr $\mathrm{BP}$ the wet period correlate, to some extent, with the high stands registered at $\mathrm{LC}$ and $\mathrm{BJ}$ sites as seen in Table 2. A weaker concordance is found after that date, when the development of a halophyte shrub steppe suggests drier conditions at Alero record and fluctuations are observed in the basin sequences. Present intra-and inter-annual lake level fluctuations of Colhue Huapi are mainly related to the amount of precipitation falling as snow during austral winters in its headwaters in the Andes mountain, while the low level is influenced by human use and by the evaporation rate due to the temperature and drying action of constant winds in the region (Calcagno et al. 1995; Coronato \& del Valle, 1988; Coronato, 2003).

\section{CONCLUSIONS}

The main changes in pollen spectrum at La Campanita site occurred in two local taxa: Cyperaceae and Chenopodiaceae, while few differences were found in the contribution of regional and extra-regional pollen. As a consequence, the sequence would be reflecting changes at a local scale. Lake level fluctuations were associated principally to changes in Cyperaceae and NPPs, Pediastrum and Botryococcus.

The paleoclimatic inferences indicate that before ca. 1212 yr BP lake level was high related to low values of Cyperaceae and the maximum percentages of Pediastrum and Botryococcus algae. Between ca. 1211 and 414 yr BP a period of changing lake water level took place. Until ca. $979{ }^{14} \mathrm{C}$ yr BP lake level was high and since then, a decrease would have occurred suggested by an increase in the representation of Cyperaceae and a reduction in algae. From ca. 414 yr BP up to 195 yr BP lake water level would have continued its reduction, as indicated by the highest percentages of Cyperaceae of the sequence and low algal proportion. Finally, for the last ca. 195 yr BP, the reduction in Cyperaceae would mark a recover trend of the lake water level.

The pollen and algae record from $\mathrm{La}$ Campanita site might contribute to our better understanding of climatic changes and vegetation relation in the Colhue Huapi system. The comparison among sites of different shores provided new insights to the reconstruction and would enhance our comprehension of the dynamics of this lake's coastline. Usually central basin cores are studied because conditions are more constants. However, Laird \& Cumming (2009) proposed that near shore cores are adequate and recommended in reconstructions attempting to infer fluctuations in lake level since shores are mainly concerned in fluctuations of water level.

The vulnerability of the lakeshore to erosion is varied and would depend on slope profile, soil composition, sediment types and compactness (Dearing, 1997). One difficulty of using near-shore cores is that it is possible that part of the sediment archive may be lacking as a result of reworking of previously deposited sediment or wave action (Laird \& Cumming, 2009).

On the whole, the present study might contribute to enlarge the background knowledge of paleoclimatic conditions of central Patagonia during the late Holocene.

Understanding changes in ecological systems over long periods of time is essential for placing modern communities in proper context (Delcourt \& Delcourt, 1991). When put in a longer context the repeated fluctuations of lake level observed in Colhue Huapi over the last years are part of a recurrent dynamics of the system and should be taken into account in the future management of the water resource and the lake ecosystem sustainability.

\section{ACKNOWLEDGEMENTS}

The authors wish to thanks Annette Aguerre and Matilde Trivi for help in collecting and providing the samples. The authors are grateful to Patricia Palacio for the assistance in laboratory processing and graphs making. ACF is indebted to the CONICET for the fellowship support. This study was 
supported by Fundación Antorchas No 14116-202, PIP-CONICET N ${ }^{\circ} 02466$, PICT $2002 \mathrm{~N}^{\circ} 04-11759$ and UNMdP EXA 562/12.

\section{LITERATURE CITED}

Bennett, K. D. \& K. J. Willis (2003). Pollen. pp: 5-32. In: J. P. Smol, H. J. B. Birks \& W. M. Last (Eds.). Tracking Environmental Change Using Lake Sediments Volume 3: Terrestrial, Algal and Siliceous Indicators. Kluwer Academic Publishers, Dordrecht, The Netherlands.

Burry, L. S. \& H. L. D’Antoni (2001). Análisis de polen en el sur de Chubut (Argentina): Reinterpretación del perfil del Alero del Cañadón de las Manos Pintadas. Asociación Paleontológica Argentina. Publicación Especial, 8, 65-72.

Calcagno, A. T., M. J. Fioriti, F. Pedrozo, H. López, C. Rey, R. Quirós \& M. E. Rasquin (1995). Catálogo de lagos y embalses de la Argentina. (Edición bilingüe). Subsecretaría de Recursos Hídricos. Ed. Ministerio de Economía y Obras Públicas. ARM \& Asociados. Buenos Aires. Argentina.

Carrapiço, F. (Coord.) (2001). Azolla em Portugal. Ed. Instituto da Água. Faculdade de Ciencias da Univerdidades de Lisboa. http://azolla. fc.ul.pt/documents/AzollaPortugal.pdf

Casal, G., R. Martínez, M. Luna, J. C. Sciutto \& M. Lamanna (2007). Aeolosaurus colhuehuapensis sp. Nov. (Sauropoda, Titanosauria) de la formación Bajo Barreal, Cretácico Superior de Argentina. Revista brasilera de paleontología, 10(1), 53-62.

Coops, H., M. Beklioglu \& T. L. Crisman (2003). The role of water-level fluctuations in shallow lake ecosystems - workshop conclusions. Hydrobiologia, 506-509, 23-27.

Coronato, F. (2003). El problema de la desecación del Lago Colhué Huapi desde La Geografía Histórica. Actas de la 64 ${ }^{\mathrm{a}}$ Semana de Geografía. GAEA, 165-170.

Coronato, F. \& H. del Valle (1988). Caracterización hídrica de las cuencas hidrográficas de la provincia del Chubut. Ed. Centro Nacional Patagónico - Consejo Nacional de Investigaciones Científicas y Técnicas (CEN-
PAT-CONICET), Puerto Madryn.

Correa, M. (dir.) (1978). Flora Patagónica - Parte III Gramineae. Colección Científica del Inta, Bs. As.

Correa, M. (1984). Flora Patagónica - Tomo VIII, Parte IV a. Colección Científica del Inta, Bs. As.

Dangavs, N. V. (1995). Morfometría de cuerpos lénticos. pp. 27-45. En: E. C. Lopretto y G. Tell (dir.) Ecosistemas de aguas continentales. Metodologías para su estudio. Ed. Sur, La Plata.

Danielsen, R. (2010). Dissimilarities in the recent histories of two lakes in Portugal explained by local-scale environmental processes. Journal of Paleolimnology, 43, 513-534.

Dearing, J. A. (1997). Sedimentary indicators of lake-level changes in the humid temperate zone: a critical review. Journal of Paleolimnology, 18, 1-14.

De la Vega, S. G. (2010). Patagonia, las leyes de la estepa. $2^{\text {a }}$ edición. Serie Explorando nuestra naturaleza. Contacto silvestre ediciones. Buenos Aires, Argentina.

Delcourt, H. R. \& P. A. Delcourt (1991). Quaternary Ecology. A paleoecological perspective. Chapman \& Hall. London.

Dodds, W. \& M. Whiles (2010). Freshwater ecology. Concepts and environmental applications of limnology. $2^{\text {nd }}$ edition. Academic Press. USA.

Donoso Z., C. \& F. Utreras (2007). Podocarpus saligna D. DON. Mañío, Mañío de hojas largas, Mañiu. Familia: Podocarpaceae. 102108. In Donoso Zegers, C. (Ed.) Las especies arbóreas de los bosques templados de Chile y Argentina. Autoecología. Marisa Cuneo Ediciones Valdivia Chile.

Donoso Z., C., F. Utreras \& A. Zúñiga (2007). Podocarpus nubigena Lindl. Mañío, Mañío de hojas punzantes, Pino amarillo, Mañío Hembra (en Chiloé), Mañío Macho (en el resto del país). Familia: Podocarpaceae. 92-101. In Donoso Zegers, C. (Ed.) Las especies arbóreas de los bosques templados de Chile y Argentina. Autoecología. Marisa Cuneo Ediciones Valdivia Chile.

Fabiani, A. C., L. S. Burry \& A. H. Escalante (2009). Fases de aguas claras y turbias en 
el lago Colhue Huapi (Chubut) durante el Holoceno tardío. Ameghiniana 46 (4): 115R-116R Suplemento Resúmenes.

Faegri, K. \& J. Iversen (1989). Textbook of Pollen Analysis. 4th ed. K. Faegri, P. E. Kalland, K. Krzywinski (eds.) Wiley and Sons, Chichester.

Fey, M., C. Korr, N. I. Maidana, M. L. Carrevedo, H. Corbella, S. Dietrich, M. M. Paez, F. A. Quintana, F. Schäbitz, \& B. Zolitschka (2009). Palaeoenvironmental changes during the last 1600 years inferred from the sediment record of a cirque lake in southern Patagonia (Laguna Las Vizcachas, Argentina). Palaeogeography, Palaeoclimatology, Palaeoecology, 281, 363-375.

Fritz, S. C. (2005). Lacustrine perspectives on Holocene climate. pp: 227-241. In: A. Mackay, R. Battarbee, J. Birks \& F. Oldfield (eds.). Global Change in the Holocene. Hodder Arnold, London.

Grimm, E. (1992). Tilia software. Illinois State Museum. Research and Collection Center Springfield, Illinois.

Grimm, E. (2004). TGView 2.02 Illinois State Museum. Research and Collection Center Springfield, Illinois.

Golluscio, R. A., Cavagnaro1, F. P. \& Valenta, M. D. (2011). Arbustos de la estepa patagónica: ¿adaptados a tolerar la sequía o el pastoreo? Ecología Austral, 21, 61-70.

Haberzettl, T., M. Fey, A. Lücke, N. Maidana, G. Mayr, C. Ohlendorf, F. Schäbitz, G. Schleser, M. Wille \& B. Zolitschka. 2005. Climatically induced lake level changes during the last two millennia as reflected in sediments of Laguna Potrok Aike, southern Patagonia (Santa Cruz, Argentina). Journal of Paleolimnology, 33, 283-302.

Heusser, C. J. (1971). Pollen and Spores from Chile. Modern Types of Pteridophyta, Gymnospermae and Angiospermae. University of Arizona Press, Tucson.

Hofmann, H., A. Lorke \& F. Peeters (2008). Temporal scales of water-level fluctuations in lakes and their ecological implications. Hydrobiologia, 613, 85-96.

Horowitz, A. (1992). Palynology of arid lands. Elsevier Science Publishers. The Netherlands.
Iglesias de Cuellos, A. (1982). Comodoro Rivadavia. In: E. Chiozza \& R. Figueira (dir.) Atlas total de la República Argentina. Centro Editor de América Latina S. A. Buenos Aires, Argentina.

Janssen, C. R. (1966). Recent pollen spectra from the deciduous and coniferous-deciduous forests of northwestern Minnesota, interpreted from pollen indicators and surface simples. Ecol monogr, 37, 145-72.

Kilian, R. \& F. Lamy (2012). A review of Glacial and Holocene paleoclimate records from

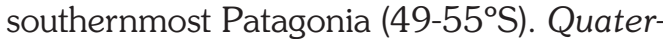
nary Science Reviews, 53, 1-23.

Laine, A., E. Gauthier, J.P. Garcia, C. Petit, F. Cruz \& H. Richard (2010). A three-thousand-year history of vegetation and human impact in Burgundy (France) reconstructed from pollen and non-pollen palynomorphs analysis. C. R. Biologies, 333, 850-857.

Laird, K. R. \& B. F. Cumming (2009). Diatom-inferred lake level from near-shore cores in a drainage lake from the Experimental Lakes Area, northwestern Ontario, Canada. Journal of Paleolimnology, 42(1), 65-80.

Livingstone, D. A., Kirk Bryan, Jr. \& R. G. Leahy, (1958). Effects of an Arctic Environment on the Origin and Development of Freshwater Lakes. Limnol Oceanogr, 3(2),192-214

León, R. J. C., D. Bran, M. Collantes, J. M. Paruelo \& A. Soriano (1998). Grandes unidades de vegetación de la Patagonia extra andina. Ecología Austral, 8, 125-144.

Mancini, M. V. (1998). Vegetational changes during the Holocene in Extra-Andean $\mathrm{Pa}$ tagonia, Santa Cruz Province, Argentina. Palaeogeography, Palaeoclimatology, $\mathrm{Pa}$ laeoecology, 138, 207-219.

Mancini, M. V. (2009). Holocene vegetation and climate changes from a peat pollen record of the forest - steppe ecotone, Southwest of Patagonia (Argentina) Quaternary Science Reviews, 28, 1490-1497.

Margalef, R. (1983). Limnología. Editorial Omega. Barcelona.

Markgraf, V. \& H. D'Antoni (1978). Pollen Flora of Argentina. Modern Spore and Pollen Types of Pteridophyta, Gymnospermae, and Angiospermae. The University of Ar- 
izona Press, Tucson.

Markgraf, V., J. P. Bradbury, A. Schwalb, S. J. Burns, Ch. Stern, D. Ariztegui, A. Gilli, F. S. Anselmetti, S. Stine \& N. Maidana (2003). Holocene palaeoclimates of southern Patagonia: limnological and environmental history of Lago Cardiel, Argentina. The Holocene, 13(4), 581-591.

Mason, I., M. Guzkowska y C. Rapley (1994). The response of lake-levels and areas to climatic change. Climatic Change, 27, 161-197.

Mayr, C.; M. Fey, T. Haberzettl, S. Janssen, A. Lücke, N. Maidana, C. Ohlendorf, F. Schäbitz, G. Schleser, U. Struck, M. Wille \& B. Zolitschka (2005). Palaeoenvironmental changes in southern Patagonia during the last millennium recorded in lake sediments from Laguna Azul (Argentina). Palaeogeography, Palaeoclimatology, Palaeoecology, 228, 203-227.

Modenutti, B. E., E. Balseiro, M. C. Diéguez, C. Queimaliños \& R. Albariño (1998). Heterogeneity of fresh-water Patagonian ecosystems. Ecología Austral, 8, 155-165.

Moore, P. D., J. A. Webb \& M. E. Collinson. (1991). Pollen Analysis, 2nd. ed. Blackwell Scientific, London.

Paruelo, J. M., Aguiar, M. R., Golluscio, R. A. \& León, R. J. C. (1992). La Patagonia extrandina: análisis de la estructura y el funcionamiento de la vegetación a distintas escalas. Ecología Austral, 2, 123-136.

Paruelo, J. M., A. Beltrán, E. Jobbágy, O. E. Sala \& R. A. Golluscio (1998). The climate of Patagonia: general patterns and controls on biotic processes. Ecología Austral, 8, 85101.

Quirós, R., R. Delfino, S. Cuch \& R. Merello (1983). Diccionario Geográfico de Ambientes Acuáticos Continentales de la República Argentina. Parte I: Ambientes Lénticos. Departamento de Aguas Continentales. Instituto Nacional de Investigación y Desarrollo Pesquero (INIDEP).

Rossi, J. B. \& N. M. Tur (1976). Autoecología de Scirpus californicus. Desarrollo del rizoma. Boletin de la Sociedad Argentina de Botánica, 17(3-4), 280-288.

Shennan, S. (2005). Holocene climate and human population: An archaeological approach. pp: 36-48. In: A. Mackay, R. Battarbee, J. Birks \& F. Oldfield (eds.). Global Change in the Holocene. Hodder Arnold, London.

Soriano, A. (1956). La vegetación de la República Argentina IV. Los distritos florísticos de la provincia Patagónica. Revista de investigaciones agrícolas, 10(4), 321-357.

Stine, S. \& M. Stine (1990). A record from Lake Cardiel of climate change in southern South America. Nature, 345, 705-707.

Stockton, C. (1990). Climatic variability on the scale of decades to centuries. Climatic Change, 16, 173-183.

Stuiver, M. \& P. Reimer (1993). Extended C14 data base and revised CALIB 3.0 C14 age calibration program. Radiocarbon, 35, 215-230.

Trivi, M.E. \& L. S. Burry (2007). Paleoambientes del Lago Colhue Huapi (Chubut, Argentina) durante el Holoceno reciente. Estudio palinológico. Revista Española de Micropaleontología, 39(3), 205-214.

van Geel, B. (2003). Non-pollen palynomorphs. In J. P. Smol, H. J. B. Birks \& W. M. Last (eds.). Tracking Environmental Change Using Lake Sediments Volume 3: Terrestrial, Algal and Siliceous Indicators. Kluwer Academic Publishers, Dordrecht, The Netherlands.

Weckström, K., J. Weckström, L.M. Yliniemi \& A. Korhola (2010). The ecology of Pediastrum (Chlorophyceae) in subartic lakes and their potential as paleobioindicators. Journal of Paleolimnology, 43, 61-73.

Whitlock, C., Bianchi, M. M., Bartlein, P. J., Markgraf, V., Marlon, J., Walsh, M. y N. McCoy (2006). Postglacial vegetation, climate, and fire history along the east side of the Andes (lat $\left.41-42.5^{\circ} \mathrm{S}\right)$, Argentina. Quaternary Research, 66, 187-201.

Wille, M., N.I. Maidana, F. Schäbitz, M. Fey, T. Haberzettl, S. Jassen, A. Lücke, C. Mayr, C. Ohlendorf, G. H. Schleser \& B. Zolitschka (2007). Vegetation and climate dynamics in southern South America: The microfossil record of Laguna Potrok Aike, Santa Cruz, Argentina. Review of Palaeobotany and Palynology, 146, 234-246. 
